\title{
Analisis Perbandingan Efisiensi BPR Konvensional dan BPR Syariah di Provinsi Jawa Timur
}

\author{
Bahrina Almas \\ Universitas Airlangga Surabaya \\ almas.muharram@gmail.com
}

\begin{abstract}
Abstrak
Penelitian ini bertujuan untuk mengetahui dan menganalisis perbandingan tingkat efisiensi antara Bank Perkreditan Rakyat Konensional dan Bank Pembiayaan Rakyat Syariah menggunakan Data Envelopment Analysis (DEA). Pengukuran technical efficiency yang menggunakan multi input dan output dalam penelitian ini diharapkan dapat menunjukkan dan mengukur perbandingan kinerja antara BPR Konvensional dan BPR Syariah di Provinsi Jawa Timur. Penelitian ini merupakan jenis penelitian kuantitatif menggunakan data sekunder dari Laporan Publikasi Keuangan yang terdapat di Otoritas Jasa Keuangan dan Bank Indonesia. Sample yang digunakan dalam penelitian ini berjumlah 10 BPR, yang terdiri dari 5 sample BPR Konvensional dan 5 sample BPR Syariah selama periode Maret 2014 sampai dengan Desember 2017. Variabel input dalam penelitian in adalah total aset, dana pihak ketiga dan biaya tenaga kerja, sedangkan variabel output yang digunakan adalah kredit atau pembiayaan dan pendapatan operasional. Hasil analisis menggunakan metode Data Envelopment Analysis (DEA) menunjukkan bahwa ada dua BPR dari 5 sample BPR Konvensional yang efisien, sedangkan tidak ada BPR yang efisien dari 5 sample BPR Syariah.
\end{abstract}

Kata Kunci: BPR, BPRS, Efisiensi, Data Envelopment Analysis.

\begin{abstract}
This study aims to find out and explain the efficiency level comparison between Conventional Rural Banks and Sharia Rural Banks using Data Envelopment Analysis (DEA) method. Technical efficiency measurement that uses multi inputs and outputs in this study is expected to show and measure the comparison of performance between Conventional Rural Banks and Sharia Rural Banks in East Java Province. This research is a type of quantitative research using secondary data from Financial Publication Reports contained in the Financial Services Authority and Bank Indonesia. The sample used in this study amounted to 10 BPR, consisting of 5 samples of Conventional Rural Banks and 5 samples of Islamic Rural Banks during the period March 2014 to December 2017. Input variables in this study were total assets, third party funds and labor costs, while variables the output used is credit or financing and operating income. The results of the analysis using the Data Envelopment Analysis (DEA) method show that there are two BPR from 5 samples of efficient Conventional Rural Banks, while there are no efficient BPR from 5 Sharia Rural Banks samples.
\end{abstract}

Keywords: BPR, BPRS, Efficiency, Data Envelopment Analysis. 


\section{Pendahuluan}

Sektor keuangan terutama industri perbankan berperan sangat penting bagi aktivitas perekonomian suatu negara. Peran strategis bank tersebut sebagai wadah yang mampu menghimpun dan menyalurkan dana masyarakat secara efektif dan efisien ke arah peningkatan taraf hidup rakyat. Bank merupakan salah satu bagian penting dari pasar keuangan selain pasar modal dan asuransi. Di Indonesia, perbankan mempunyai pangsa pasar sebesar $80 \%$ dari keseluruhan sistem keuangan yang ada (Bank Indonesia, 2009). Efisiensi sektor perbankan merupakan salah satu isu yang sangat menarik bagi para ahli ekonomi di seluruh dunia.

Di Indonesia, ada dua jenis bank, yakni: (1) Bank Umum; (2) Bank Perkreditan Rakyat. Perkembangan industri perbankan syariah di Indonesia menjadi demikian pesatnya sejak didirikannya Bank Umum Syariah pertama di Indonesia pada tahun 1992. Dari segi kelembagaan, tercatat sampai Februari 2017 Indonesia memiliki 13 Bank Umum Syariah dan 21 Unit Usaha Syariah. Sedangkan, Bank Perkreditan Syariah sampai Februari 2017 berjumlah 166 BPRS. $^{1}$ Perkembangan signifikan juga terjadi di Jawa Timur sebagai provinsi yang memiliki BPR dan BPRS terbanyak di Indonesia. Tercatat hingga Februari 2017, Jawa Timur memiliki 31 BPRS, baik milik pemerintah maupun swasta terbanyak dibandingkan provinsi lain di Indonesia. Sedangkan untuk BPR, Jawa Timur memiliki 321 BPR, merupakan jumlah paling banyak se-Indonesia. ${ }^{2}$

Pertumbuhan ekonomi Indonesia pada kuartal I 2017 berada pada angka 5.01 persen atau lebih tinggi dibandingkan pertumbuhan kuartal I 2016 di kisaran 4.92 persen. Angka tersebut juga lebih

\footnotetext{
Otoritas Jasa Keuangan. Statistik Perbankan Syariah (Sharia Banking Statistic). (Jakarta: Otoritas Jasa Keuangan, 2017)

${ }^{2}$ Lihat pada http://www.bi.go.id/id/statistik/perbankan/bprkonvensional/indikatorutama/Default.aspx.
}

dibandingkan pertumbuhan kuartal IV 2016 sebesar 4.94 persen. Pertumbuhan ekonomi pada tiga bulan pertama tahun 2017 ditopang oleh kinerja perdagangan ekspor dan dan impor yang berhasil surplus, karena adanya sentiment positif dari perbaikan harga sejumlah komoditas dunia juga ekonomi global yang mengalami peningkatan. Akan tetapi pertumbuhan ekonomi Indonesia tidak lantas mencerminkan pertumbuhan kredit yang baik dari sektor perbankan. Pertumbuhan kredit yang lemah, menyulut melemahnya kredit perbankan karena kurangnya permintaan kredit oleh dunia usaha di tengah perlambatan ekonomi global.

Muhari dan Hossen (2014) menyatakan bahwa keberadaan BPR dan BPRS memiliki tujuan untuk menyediakan jasa dan produk perbankan bagi masyarakat golongan ekonomi lemah dan usaha kecil dan mikro (UKM) baik di perkotaan maupun di pedesaan. Secara umum BPR dan BPRS memiliki tujuan dan karakteristik yang relatif sama dengan Lembaga Keuangan Mikro (LKM), yakni komersial dan pengembangan masyarakat (Buchori, 2003).

Komersial artinya LKM dalam menjalankan usahanya harus memperoleh keuntungan agar kegiatan operasional sustainable dan kemampuan melayani nasabah semakin meningkat (outreach). Hal itu sangat berkaitan dengan tujun kedua, yakni pengembangan masyarakat. Masyarakat yang menjadi prioritas penyaluran dana adalah mayarakat dengan ekonomi lemah atau yang tidak dapat menjangkau perbankan komersial. Sehingga, dengan adanya BPR dan BPRS misi lembaga keuangan untuk memberdayakan masyarakat, menciptakan lapangan pekerjaan, mengembangan usaha nasabah yang pada akhirnya mengurangi kemiskinan akan tercapai.

Sektor Usaha Mikro, Kecil dan Menengah (UMKM) menjadi andalan perekonomian Jawa Timur, khususnya dalam menghadapi Masyarakat Ekonomi 
ASEAN (MEA). Selain UMKM menjadi kontributor terbesar bagi PDRB Jawa Timur, sektor UMKM telah terbukti mampu bertahan dan terus tumbuh meskipun situasi ekonomi global sedang lesu. Di Jawa Timur, koperasi dan UMKM tumbuh pesat terbukti pada tahun 2008, terdapat 4.2 juta UMKM dan pada tahun 2015, jumlah UMKM tumbuh menjadi 6.8 juta dengan kontribusi terhadap Produk Domestik Regional Bruto (PDRB) yang tinggi, yakni sebesar $54.98 \%$ dari total $\mathrm{Rp} 1689.88$ Triliun PDRB Jawa Timur dan menyerap sebanyak 11.12 juta tenaga kerja atau 92\% dari seluruh tenaga kerja di Jawa Timur. Akan tetapi, potensi yang begitu besar dari UMKM tidakdidukung oleh sektor perbankan karena UMKM masih mengalami kesulitan untuk mengakses modal di perbankan. Sehingga pemerintah Jawa Timur perlu untuk mendorong sistem perbankan yang dapat mendukung kesejahteraan perekonomian masyarakat melalui pernyaluran kredit kepada UMKM.

Penelitian-penelitian pada bidang ekonomi dan bisnis pada dasarnya bertujuan untuk memaksimalkan hasil dari sumber daya yang terbatas, sehingga penelitian tentang efisiensi khususnya pada tingkat perusahaan merupakan hal yang sangat penting dalam bidang ekonomi dan bisnis. Berbeda dengan Bank Umum, Bank Perkreditan Rakyat adalah bank yang melaksanakan kegiatan usaha secara konvensional atau berdasarkan prinsip syariah yang dalam kegiatannya tidak memberikan jasa lalu lintas pembayaran. BPR memiliki penetrasi yang lebih baik dibandingkan dengan bank umum khususnya untuk usaha mikro kecil dan menengah (UMKM).

Keberhasilan BPR dalam memberikan pelayanan kepada UMKM antara lain adalah lokasi BPR yang lebih dekat dengan pasar, prosedur pelayanan yang sederhana, proses yang lebih cepat dan pendekatan personal (relationship marketing) yang lebih baik terhadap pelanggan (Suliyanto dan Jati, 2014). Menurut Hartono et.al (2008) meskipun skala ekonomis BPR masih kecil, namun kemampuannya dalam memberikan akses keuangan yang lebih luas kepada Usaha Menengah dan Kecil di Indonesia sangatlah penting.

Pengukuran efisiensi dalam dunia perbankan adalah salah satu parameter kinerja yang cukup populer. Hal itu banyak digunakan karena dapat menjawab kesulitan-kesulitan dalam menghitung ukuran kinerja perbankan. Rasio biaya operasional terhadap pendapatan operasional (BOPO) yang selama ini sering digunakan untuk mengukur efisiensi perbankan memiliki kelemahan karena sulit untuk menyamaratakan apakah suatu rasio baik atai buruk dan sulit untuk menyatakan apakah perusahaan tersebut kuat atau lemah dan tidak memperhitungkan biaya modal. ${ }^{3}$ Oleh karena itu, kemudian pendekatan frontier dikembangkan dan dibagi menjadi dua pendekatan, yakni: (1) pendekatan nonparametrik dan (2) pendekatan parametrik. Pendekatan non-parametrik adalah data envelopment analysis (DEA) dan free disposable hull (FDH), sedangkan pendekatan parametrik adalah stochastic frontier approach (SFA) dan distribution free approach (DFA).

Metode DEA ini mampu menganalisis kinerja beberapa objek atau decision making unit (DMU) berdasarkan rasio output terhadap input sehingga dapat dibuat garis efisien guna memperoleh rasio maksimal yang dicapai DMU tertentu. Konsep-konsep yang digunakan dalam mendefiniskan hubungan input-output perilaku lembaga keuangan pada metode parametrik DEA adalah pendekatan produksi (production approach), pendekatan intermediasi (intermediation approach) dan pendekatan aset (asset approach). Cooper et al. (2007) dalam menyatakan bahwa DEA sebagai alat

\footnotetext{
3 Endri dan Abdul Wakil. Analisis Kinerja Keuangan dengan Menggunakan Rasio-Rasio Keuangan dan Economic Value Added (Studi Kasus: PT. Bank Syariah Mandiri). Jurnal Ekonomi, 1(13):123-140. 2008
} 
analisis untuk mengukur efisiensi memiliki beberapa keunggulan, yakni dapat digunakan untuk menganalisis kasus yang memiliki hubungan kompleks di antara berbagai input dan output dalam satu lembaga atau aktivitas yang tidak mampu dipecahkan dengan menggunakan alat analisis lain, serta dapat mengidentifikasi sejumlah variabel disertai hubungan yang banyak seperti halnya program matematik (Suliyanto dan Jati, 2014)

Penelitian sebelumnya terkait efisiensi lembaga keuangan kebanyakan dilakukan di negara-negara maju (Kwan dan Eisenbeis, 1996 di perbankan Amerika Serikat; Worthington, 1998 di perbankan Australia; dan Koetter; 2005 di perbankan Jerman) sedangkan untuk lembaga keuangan Islam banyak dilakukan di negara-negara yang pertumbuhan ekonomi Islamnya pesat, seperti Malaysia. Analisis perbandingan efisiensi antara BPR Konvensional dan BPR Syariah menarik untukditeliti, hal ini disebabkan adanya perbedaan dari sisi kredit dan atau pembiayaan. Disamping itu, penelitian sebelumnya banyak yang membedakan BUS dan BUK (Ismail et al., 2013; Wahab, Hosen dan Muhari, 2014; Sari dan Suprayogi, 2015), atau hanya membahas tingkat efisiensi BPRS saja (Warninda dan Hosen, 2015; Nashihin dan Harahap, 2014; Hosen dan Muhari, 2013). Penelitian terkait perbandingan tingkat efisiensi BPR Konvensional dan BPR Syariah di Jawa Timur belum pernah dilakukan.

Berdasarkan latar belakang tersebut, tujuan penelitian ini adalah (1) menganalisis tingkat efisiensi BPR Konvensional di Jawa Timur antara kuartal I 2014 sampai dengan kuartal IV 2017 menggunakan data envelopment analysis (DEA); menganalisis tingkat efisiensi BPR Syariah di Jawa Timur antara kuartal I 2014 sampai dengan kuartal IV 2017 menggunakan data envelopment analysis (DEA). Variabel input yang digunakan adalah total aset, dana pihak ketiga (DPK) dan biaya tenaga kerja, sedangkan variabel output yang digunakan adalah pembiayaan atau kredit dan pendapatan operasional.

Analisis efisiensi terhadap BPRK dan BPRS di Jawa Timur ini dapat memberikan informasi terkait tingkat efisiensi dari sejumlah sampel BPRK dan BPRS yang diambl sehingga pihak Otoritas Jasa Keuangan dan Bank Indonesia dapat merumuskan strategi pengawasan yang tepat bagi setiap BPRK dan atau BPRS di Jawa Timur, terlebih dapat mendorong untuk evaluasi kinerja BPR nasional. Bagi industri perbankan penelitian ini dapat bermanfaat untuk mengukur tingkat efisiensi usaha bank dibandingkan dengan tingkat efisiensi bank pesaing dalam suatu kelompok bank terkait, sehingga dapat digunakan sebagai dasar untuk merumuskan strategi usahanya di waktu yang akan datang.

\section{Pembahasan}

\section{Bank sebagai Lembaga Intermediasi}

Menurut Rahardja dan Manurung (2006) dalam Muhari dan Hosen (2014) bank merupakan salah satu lembaga keuangan (financial institutions) yang kegiatan utamanya adalah menghimpun dana dari unit surplus untuk disalurkan dalam bentuk kredit kepada unit defisit. Unit surplus yang dimaksud adalah orangorang atau lembaga yang memiliki kelebihan dana (likuiditas), sedangkan unit defisit adalah unit rumah tangga atau perusahaan yang menggunakan dana untuk kegiatan konsumsi atau kegiatan-kegiatan lain yang diharapkan dapat memberi keuntungan di masa yang akan datang.

Sebagai salah satu lembaga intermediasi, BPR mempunyai karakteristik yang berbeda dengan bank umum, yakni: (1) BPR tidak diperbolehkan untuk menerima simpanan berupa giro dan ikut serta dalam lalu lintas pembayaran; (2) dilarang melakukan kegiatan usaha dalam valuta asing; (c) dilarang melakukan penyertaan modal; (d) dilarang melakukan 
usaha perasuransian; (e) dilarang melakukan usaha lain di luar kegiatan usaha sebagaimana dimaksud dalam pasal 13 Undang-Undang No. 7 Tahun 1992 tentang Perbankan yang diubah dengan UndangUndang No. 23 Tahun 1999 (Siamat, 199).

Sebelum didirikannya BPR Syariah di Indonesia, masyarakat terlebih dulu mengenal adanya Bank Perkreditan Rakyat (BPR). Dalam UU No. 21 Tahun 2008 disebutkan bahwa BPR adalah bank konvensional yang dalam kegiatannya tidak memberikan jasa dalam lalu lintas pembayaran. BPR masih menerapkan sistem bunga dalam kegiatan operasionalnya. Oleh karena itu, penyebutan 'perkreditan' dalam BPR Konvensional seharunya menjadi 'pembiayaan' dalam BPR Syariah. Perbedaan Bank Pembiayaan Rakyat Syariah (BPRS) dengan Bank Perkreditan Rakyat Kovensional (BPR Konvensional), yaitu: (1) akad dan legalitas; (2) adanya Dewan Pengawas Syariah; (3) penyelesaian sengketa melalui Badan Arbitrase Syariah maupun Pengadilan Agama; (4) pelarangan melakukan bisnis haram, syubhat dan yang menimbulkan mudharat bagi pihak lain; (5) sistem bagi hasil dalam penghimpunan maupun penyaluran pembiayaan.

\section{Konsep Efisiensi Persepektif Islam}

Menurut Affandi (2002), setiap Muslim dalam menjalankan bisnis haruslah berkeinginan kuat untuk meningkatkan efisiensi, yakni dengan mengurangi biaya demi kebaikan konsumennya. Konsep efisensi tersebut sejalan dengan prinsip ekonomi Islam yang bertujuan untuk mencapai salah satu maqashid syariah, yaitu terpeliharanya al-maal (Kamaruddin, 2008). Konsep ini terkandung dalam QS. AlIsraa'[17]:26-27:

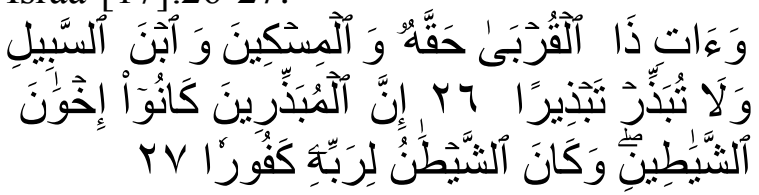

Waa@tidza al-qurba@haqqahuwa al-miski@ina wa abna as-sabi@liwa la@ tubadzdzir tabdzi@ran.
Inna al-mubadzdziri@na ka@nu@ikhwa@na asysyaya@ti@niwaka@na asy-syaitha@nu lirabbihi@ kafu@ran.

"Dan berikanlah kepada keluarga-keluarga yang dekat akan haknya, kepada orang miskin dan orang yang dalam perjalanan dan janganlah kamu menghambur-hamburkan (hartamu) secara boros. Sesungguhnya pemboros-pemboros itu adalah saudarasaudara syaitan dan syaitan itu adalah sangat ingkar kepada Tuhannya."(QS. Al-Israa' [17]:26-27)

Kata boros berasal dari kata tabdzir yang merupakan kata kerja (fi'il) dari kata sifat (isim) mubadzir yang oleh Imam Syafi'i dimaknai sebagai membelanjakan harta tidak pada jalannya. Mujahid juga menjelaskan bahwa walaupun seluruh harta dihabiskan untuk jalan yang bear, maka tidak dikategorika sebagai mubadzir. Sebaliknya, walaupu hanya segantangpadi tapi digunakan untuk hal yang tidak benar maka hal itu dapat disebut dengan mubadzir. ${ }^{4}$ Berdasarkan konsep efisiensi dalam pandangan di atas, makakonsep efisiensi kinerja pembiayaan pada Bank Pembiayaan Rakyat Syariah merujuk pada keharusan manajemen BPR untuk mengupayakan pengelolaan pengeluaran untuk pos-pos penggerak biaya dengan cara yang tepat guna, benar, wajar dan hemat. Hal ini sebagaimana terkandung dalam hadits yang diriwayatkan oleh Ishaq bin Ibrahim Al Handlali ${ }^{5}$ :

Dan telah menceritakan kepada kami (Ishaq bin Ibrahim Al-Handlali) telah mengabarkan kepada kami (Jarir) dari Manshur dari Asy-Sya'bi dari Warrad bekas budak Al-Mughirah bin Syu'bah, dari Mughirah bin Syu'bah dari Rasulullah SAW. Sesungguhnya Rasulullah SAW bersabda: "Sesungguhnya Allah 'azza wa jalla mengharamkan kalian mendurhakai seorang ibu, mengubur anak perempuan

\footnotetext{
${ }^{4}$ Hamka. Tafsir Al-Azhar Jus XV. Jakarta: Pustaka Panjimas, 2007.

${ }^{5}$ Abu Husain Muslim bin Al-Hajjaj. Shahih Muslim Jilid I. Kairo: Dar Al-Kutub, 1918.
} 
hidup-hidup dan tidak suka memberi dan suka meminta-minta. Dan membenci atasmu tiga perkara: mengatakan sesuatu yang tidak jelas sumbernya, banyak bertanya dan menyia-nyiakan harta." Dan telah menceritakan kepadaku (Al-Qasim bin Zakaria) telah menceritakan kepada kami ('Ubaidullah bin Musa) dari (Syaiban) dari (Manshur) dengan isnad seperti ini, hanya saja ia menyebutkan, 'Dan Rasulullah SAW telah mengharamkan atas kalian', tidak menyebutkan, 'Sesungguhnya Allah SWT mengharamkan atas kalian."(HR. Muslim No. 3237)

\section{Efisiensi Bank}

Menurut ilmu ekonomi, konsep efisiensi berasal dari konsep ekonomi mikro, yakni teori konsumen dan teori produsen. Sudut pandang teori konsumen mencoba untuk memaksimalkan kegunaan atau kepuasan individu sedangkan sudut pandang teori produsen mencoba untuk memaksimalkan profit atau meminimalkan biaya. Efisiensi sebagai perbandingan antara keluaran (output) dan masukan (input) atau jumlah yang dihasilkan dari satu input yang dipergunakan. Suatu perusahaan dapat dikatakan efisien apabila menggunakan jumlah unit yang lebih sedikit bila dibandingkan dengan jumlah unit input yang digunakan perusahaan lain untuk menghasilkan jumlah ouput yang lebih besar (Noor, 2013).

Suatu perusahaan dikatakan efisien apabila menggunakan input yang lebih sedikit dari jumlah input pada umumnya, tetapi menghasilkan output yang lebih banyak atau dapat menghasilkan minimal sama besarnya. Ada tiga faktor yang menyebabkan efisiensi, yakni: (1) apabila dengan input yang sama dapat menghasilkan output yang lebih besar; (2) dengan input yang lebih kecil dapat menghasilkan output yang sama; dan (3) dengan input yang lebih besar dapat menghasilkan jumlah output dengan presentase yang lebih.
Menurut Kamaruddin (2008), konsep efisiensi dalam kegiatan ekonomi merupakan salah satu prinsip yang penting. Setiap Muslim dalam menjalankan kegiatan ekonomi, khususnya bisnis, haruslah memiliki keinginan kuat untuk meningkatkan efisiensi, yaitu dengan mengurangi biaya demi kebaikan konsumennya. Konsep efisiensi sejalan dengan prinsip Syariah untuk mencapai dan menjaga maqashid syariah, yaitu terpeliharanya al-maal. Kesulitan utama dalam pengukuran output bank muncul karena tidak adanya konsensus dalam literatur tentang bagaimana mendefinisikan dan mengukur jasa terseb secara luas, output bank seharusnya mencakup pengelolaan portofolio dan jasa konsultasi yang disediakan oleh bank dalam kapasitasnya sebagai lembaga intermediasi.

Kesulitan mendasar muncul dalam memperlakukan simpanan bank (bank deposit) pada status input-output dari deposit tersebut. Pada umumnya, deposit dipandang sebagai input-output dari deposit tersebut. Pada umumnya, deposit dipandang sebagai input utama produksi pinjaman dan penerimaan atau perolehan dari earning assets. Namun demikian, produksi deposit yang bernilai tambah tinggi seperti tabungan, rekening koran, dana investasi, deposito dalam valuta asing, menegaskan karakteristik output dari deposit (Kusumawardani, 2008).

\section{Pengukuran Efisiensi Bank}

Konsep efisiensi pertama kali diperkenalkan oleh Farrel (1957) yang merupakan tindak lanjut dari model yang diajukan oleh Debreu (1951) dan Koopmans (1951). Konsep pengukuran efisiensi Farrel (1951) dapat memperhitungkan input majemuk, efisiensi sebuah perusahaan terdiri dari dua komponen, yakni efisiensi teknis dan efisiensi alokatif. Efisiensi teknis menunjukkan kemampuan perusahaan untuk mencapai ouput semaksimal mungkin dari sejumpah input. Sedangkan efisiensi 
alokatif menunjukkan kemampuan perusahaan untuk menggunakan input dengan proporsi seoptimal mungkin pada tingkat harga input tertentu. Kedua komponen ini kemudian dikombinasikan untuk menghasilkan ukuran efisiensi total atau efisiensi ekonomis (economic efficiency) (Abidin dan Endri, 2009).

Menurut Silkman (1986) dalam Muharam dan Pusvitasari (2007), ada tiga jenis pendekatan pengukuran efisiensi khususnya perbankan, yaitu: (1) pendekatan rasio; (2) pendekatan regresi; dan (3) pendekatan frontier. Dengan adanya pendekatan frontier untuk mengukur efisiensi, perhitungan kinerja lembaga keuangan lebih difokuskan pada pendekatan frontier efficiency.

Pada dasarnya ada tiga metode dalam data envelopment analysis (DEA) yang telah dikembangkan untuk mendefinisikan hubungan input-output dalam lembaga keuangan, sebagai berikut: (1) pendekatan produksi (Sherman dan Gold, 1995) menganggap bahwa model lembaga keuangan sebagai produsen atas deposit dan pinjaman dan mendefinisikan output sebagai jumlah tenaga kerja, pengeluaran modal pada aset-aset tetap dan material lainnya; (2) pendekatan Intermediasi (Berger dan Humprey, 1997) berdasarkan pendekatan intermediasi, lembaga keuangan bertindak sebagai perantara antara penabung dan peminjam dan menjadikan total kredit dan sekuritas sebagai output, sedangkan deposito dengan tenaga kerja dan modal fisik didefinisikan sebagai input; (3) pendekatan Aset (Favero dan Papi, 1995) memandang lembaga keuangan sebagai pencipta pinjaman dan mendefiniskan output sebagai stok pinjaman dan aset investasi (Setiawan, 2013).

Metode yang digunakan untuk mengukur efisiensi suatu unit kegiatan ekonomi (DMU) adalah analisis rasio parsial, analisis regresi berganda dan Data Envelopment Analysis (DEA) (PAU UGM,
2000). Metode DEA mampu mengatasi keterbatasan dari analisis rasio parsial dan analisis regresi berganda. Metode ini dirancang khusus untuk mengukur efisiensi relative suatu DMU yang menggunakan multi output dan multi input. Efisiensi didefinisikan sebagai rasio dari total output tertimbang dibagi dengan total input tertimbangnya. DEA mengasumsikan bahwa setiap DMU akan memilih bobot yang memaksimumkan rasio efisiensinya. Suatu DMU dikatakan efisien jika memiliki skor efisiensi sebesar 1 atau $100 \%$ dan dikatakan kurang efisien jika memiliki skor efisiensi kurang dari 1 atau 100\%.

\section{Pengembangan Hipotesis}

Penelitian Suliyanto dan Jati (2014) berjudul "Perbandingan Efisiensi Bank Perkreditan Rakyat dan Bank Umum dengan Pendekatan Data Envelopment Analysis" memperoleh kesimpulan bahwa tingkat efisiensi bank umum maupun BPR belum mencapai efisiensi sempurna (100\%), dengan rata-rata tingkat efisiensi bank umum selama periode penelitian tahun 2009-2011 adalah 86\% sedangkan rata-rata tingkat efisiensi BPR adalah $87 \%$. Penyebab inefisiensi baik bank umum maupun BPR adalah dua hal, yakni: (1) biaya tenaga kerja yang melebihi target optimal; (2) BPR mengalami permasalahan iddle fund (dana menganggur). Dari hasil penelitian empiris tersebut, maka ditarik hipotesis:

$H_{1}$ : tingkat efisiensi Bank Perkreditan Rakyat Konvensional (BPRK) pada periode 2014-2017 belum mencapai tingkat efisiensi sempurna (100\%).

Penelitian tentang tingkat efisiensi Bank Pembiayaan Rakyat Syariah oleh Muhari dan Hosen (2014) berjudul "Tingkat Efisiensi BPRS di Indonesia: Perbandingan Metode SFA dengan DEA dan hubungannya dengan CAMEL" berkesimpulan bahwa secara statistik selama periode penelitian tahun 2011-2013, efisiensi BPRS menggunakan metode DEA berada padakisaran $0,76-0,87$ sebesar $8 \%$ 
atau sebanyak 6 BPRS, nilai efisiensi antara 0,65-0,76 ada 19 BPRS atau 26\%. Adapun BPRS yang inefisiensi dengan nilai $<0,65$ berjumlah 39 BPRS atau 54\%, sedangkan yang memiliki nilai efisiensi $>0,87$ sebanyak 9 BPRS atau 12\%. Dari hasil penelitian ini dapat ditarik hipotesis:

$\mathrm{H}_{2}$ : tingkat efisiensi Bank Pembiayaan Rakyat Syariah (BPRS) pada periode 20142017 belum mencapai efisiensi sempurna (100\%).

\section{Metode Penelitian}

\section{Ruang Lingkup Penelitian}

Ruang lingkup penelitian ini meliputi analisis efisiensi teknik dan data yang digunakan adalah data kuantitatif, yaitu penelitian yang menganalisa data yang berbentuk angka (numerik). Ini dilakukan dalam jangka waktu empat tahun, yakni dari tahun 2014 sampai dengan tahun 2017. Penelitian ini dilakukan dengan melihat laporan keuangan triwulanan dari Otoritas Jasa Keuangan dalam Statistik Perbankan Indonesia dan mengambil sampel BPR Konvensional dan BPR Syariah.

\section{Jenis dan Sumber Data}

Jenis penelitian ini menggunakan jenis penelitian kuantitatif. Desain penelitian ini adalah deskriptif-komparatif, karena menggambarkan keadaan efisiensi serta membandingkan tingkat efisiensi Bank Pekreditan Rakyat Konvensional (BPRK) dan Bank Perkreditan Rakyat Syariah (BPRS). Data yang dihimpun merupakan data sekunder, yakni data berasal dari Kajian Ekonomi dan Keuangan Regional Provinsi Jawa Timur, website resmi Otoritas Jasa Keuangan dan Bank Indonesia, Laporan Publikasi Keuangan Triwulan BPR Konvensional dan BPR Syariah.

\section{Populasi dan Teknik Pengambilan Sampel}

Populasi yang digunakan dalam penelitian ini adalah BPR Konvensional dan BPR Syariah di Jawa Timur pada periode Maret 2014-Desember 2017. Sedangkan sampel untuk penelitian ini diambil dari populasi BPR Konvensional dan BPR Syariah di Jawa Timur yang beroperasi pada periode Maret 2014-Desember 2017.

Purwanto dan Sulistyatuti (2011) menjelaskan bahwa pengambilan sampel dilakukan menggunakan teknik purposive sampling. Purposive sampling adalah pengambilan sampel berdasarkan keperluan penelitian. Artinya, setiap unit/individu yang diambil dari populasi dipilih dengan sengaja berdasarkan pertimbangan tertentu. Kriteria sampel dalam penelitian ini, yakni Bank Pekreditan Rakyat Konvensional (BPRK) dan Bank Perkreditan Rakyat Syariah (BPRS) adalah 5 Bank Pekreditan Rakyat Konvensional (BPRK) dan 5 Bank Perkreditan Rakyat Syariah (BPRS) yang beroperasi di Jawa Timur selama periode tahun 2014-2017, menyajikan laporan keuangan triwulanan selama periode tahun 2014-2017, memiliki aset terbesar pada periode 2014-2017.

Tabel 1. Sampel BPR Konvensional dan BPR Syariah di Jawa Timur

\begin{tabular}{ll}
\hline \multicolumn{1}{c}{ BPR Konvensional } & \multicolumn{1}{c}{ BPR Syariah } \\
\hline PT. BPR Benta Tesa & $\begin{array}{l}\text { PT. BPRS Bakti Makmur } \\
\text { Indah }\end{array}$ \\
PT. BPR Nusamba & PT. BPRS Lan Tabur \\
Genteng & Tebuireng \\
PT. BPR Bina Reksa & PT. BPRS Amanah \\
Karya Utama & Sejahtera \\
PT. BPR Delta Purnama & PT. BPRS Mandiri Mitra \\
Sidoarjo & Sukses \\
PT. BPR Arta Nawa & PT. BPRS Bumi Rinjani \\
& Kepanjen \\
\hline Sumber: Data Diolah &
\end{tabular}

\section{Metode Pengumpulan Data}

Metode pengumpulan data yang digunakan dalam penelitian ini adalah dengan metode dokumentasi, yaitu metode yang menghimpun informasi dan data melalui metode studi pustaka, eksplorasi literatur-literatur dan laporan keuangan yang dipublikasikan oleh Otoritas Jasa Keuangan (OJK).

Penelitian ini menggunakan data sekunder, yakni data yang tidak secara langsung dikumpulkan oleh orang yang 
berhubungan langsung dengan data tersebut. Data sekunder pada umumnya digunakan oleh peneliti untuk memberikan gambaran tambahan dan sebagai pelengkap untuk selanjutnya diproses. Data sekunder penelitian ini didapatkan dari himpunan hasil penelitian lembaga seperti OJK yang diperoleh dari laporan publikasi keuangan dalam bentuk Statistik Perbankan Indonesia selama periode pengamatan dari tahun 2014-2017. Data sekunder yang dibutuhkan dalam penelitian ini adalah sebagai berikut:

Tabel 2. Jenis dan Sumber Data

\begin{tabular}{|c|c|c|}
\hline $\begin{array}{c}\text { Variabel } \\
\text { BPR } \\
\text { Konvensional }\end{array}$ & $\begin{array}{l}\text { Variabel } \\
\text { BPR } \\
\text { Syariah }\end{array}$ & $\begin{array}{c}\text { Sumber } \\
\text { Data }\end{array}$ \\
\hline Total Aset & Total Aset & OJK \\
\hline $\begin{array}{l}\text { Dana Pihak } \\
\text { Ketiga }\end{array}$ & $\begin{array}{c}\text { Dana Pihak } \\
\text { Ketiga }\end{array}$ & OJK \\
\hline $\begin{array}{c}\text { Biaya } \\
\text { Tenaga } \\
\text { Kerja }\end{array}$ & $\begin{array}{l}\text { Biaya } \\
\text { Tenaga } \\
\text { Kerja }\end{array}$ & OJK \\
\hline Total Kredit & $\begin{array}{c}\text { Total } \\
\text { Pembiayaan }\end{array}$ & OJK \\
\hline $\begin{array}{c}\text { Total } \\
\text { Pendapatan }\end{array}$ & $\begin{array}{c}\text { Total } \\
\text { Pendapatan }\end{array}$ & OJK \\
\hline
\end{tabular}

\section{Data Envelopment Analysis (DEA)}

Pendekatan frontier dikembangkan untuk menganalisis efisiensi perusahaan. Berger dan Humphrey (1997) membagi pengukuran efisiensi menjadi dua pendekatan, yakni parametrik dan nonparametrik. ${ }^{6}$ Penelitian ini menggunakan pendekatan non-parametrik, yaitu Data Envelopment Analysis (DEA) untuk mengukur tingkat efisiensi Bank Pekreditan Rakyat Konvensional (BPRK) dan Bank Perkreditan Rakyat Syariah (BPRS), karena menurut Fredella dan Diana (2014) metode Data Envelopment Analysis (DEA) memiliki kelebihan dapat mengidentifikasi input dan output suatu bank yang digunakan sebagai referensi yang dapat membantu untuk mencari penyebab dan jalan keluar

\footnotetext{
${ }^{6}$ A.N Berger dan Humphrey, D.B. Efficiency of Financial Institutions: International Survey and Directions for Future Research. European Journal of Operation Research, 98(5): 175-212 Tahun 1997.
}

dari sumber ketidakefisienan suatu bank. Secara umum model DEA, yaitu:

Dalam DEA, ada dua model yaitu, CCR dan BCC. BCC merupakan pengembangan model CCR yang pertama kali dikenalkan oleh Charnes (1978). Perbedaan kedua model tersebut terletak pada asumsi model yang digunakan. Model CCR menggunakan asumsi constant returns to scale (CRS) yang berarti satu unit input akan menghasilkan unit output yang fixed. Sedangkan model BCC menggunakan asumsi variable returns to scale (VRS), yakni input oriented dan output oriented. Penelitian ini menggunakan model CCR dengan asumsi VRS, karena penelitian ini ingin mengetahui tingkat efisiensi sebenarnya tanpa dibatasi oleh kendala apapun (Muhari dan Hossen, 2014).

Metode DEA sebagai metode pengukuran efisiensi antar unit ekonomi suatu himpunan (set). Orientasi yang digunakan adalah orientasi input (BCC_I), artinya 5 sampel BPR Konvensional dan 5 sampel BPR Syariah akan melakukan minimisasi input untuk mendapatkan tingkat output tertentu. Model yang digunakan adalah Variabel Return to Scale (VRS), skala proses kegiatan 5 sampel BPR Konvensional dan 5 sampel BPR Syariah dimungkinkan mengalami increasing return to scale, decreasing return to scale atau constant return to scale. Model VRS ini diberlakukan untuk mengantisipasi perbedaan awal kondisi skala ekonomi dari masing-masing sampel BPR Konvensional dan BPR Syariah yang diukur dengan metode Data Envelopment Analysis (DEA).

$$
\begin{aligned}
& \text { Eff }=\text { Min } \sum_{i=1}^{m} V i X i j+U o \\
& . \sum_{r=1}^{s} U r Y r j-\sum_{i=1}^{m} V i X i j+U o \geq \\
& 0 ; j=1, \ldots . n \\
& \sum_{r=1}^{s} U r Y r j=1
\end{aligned}
$$




$$
\begin{aligned}
& U r \geq 0 ; r=1, \ldots s \\
& V i \geq 0 ; i=1, \ldots m
\end{aligned}
$$

Keterangan:

$$
\begin{aligned}
& \mathrm{n} \quad=\text { jumlah unit ekonomi } \\
& \mathrm{m} \quad=\text { jumlah input } \\
& \mathrm{j}=\text { = unit ekonomi } \mathrm{j} \\
& \mathrm{i} \quad=\text { input } \mathrm{i} \\
& \mathrm{r}=\text { input } \mathrm{r} \\
& \mathrm{s} \quad=\text { jumlah output } \\
& \mathrm{V}, \mathrm{U}, \mathrm{X}, \mathrm{Y}=\text { bobot/ukuran } \\
& \mathrm{Vi}=\text { bobot yang diberikan untuk input } \mathrm{i} \\
& \text { yang dimiliki unit ekonomi } \mathrm{j}
\end{aligned}
$$

Pengukuran efisiensi menggunakan Data Envelopment Analysis (DEA) memiliki tiga pendekatan, yakni production approach (pendekatan produksi), intermediary approach (pendekatan intermediasi) dan asset approach (pendekatan asset). Dalam penelitian ini menggunakan pedekatan intermediasi (intermediary approach), dimulai dengan menentukan variabel input dan variabel output pada BPRK dan BPRS dengan sampel dari periode tahun 2014-2017. Pendekatan intermediari dipilih karena, menurut Berger dan Humphrey (1997), dinilai lebih tepat untuk mengevaluasi kinerja lembaga keuangan secara umum karena karakteristik lembaga keuangan sebagai financial intermediation yang menghimpun dana dari surplus unit dan menyalurkannya kepada defisit unit.

\section{Definisi Operasional Variabel}

Variabel-variabel yang digunakan dalam penelitian ini, sebagai berikut:

Tabel 3. Variabel Input-Output Penelitian

\begin{tabular}{lll}
\hline Pendekatan & Input & Output \\
\hline
\end{tabular}

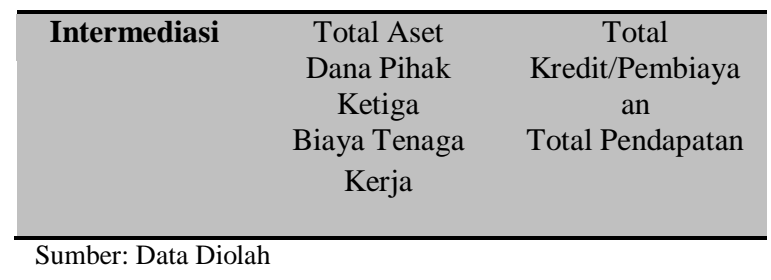

Berikut ini adalah definisi operasional dari variabel-variabel penelitian tersebut:

1. Variabel Input

Variabel input adalah variabel yang mempengaruhi variabeloutput. Ada tiga variabel input yang digunakan dalam penelitian ini, meliputi:

\section{a. Total Aset}

Total aset adalah seluruh kekayaan yang dimiliki oleh bank meliputi, kas; giro pada Bank Indonesia; penempatan pada bank lain; surat berharga yang dimiliki; pembiayaan atau kredit dan aktiva tetap yang dimiliki.

\section{b. Dana Pihak Ketiga}

Menurut Peraturan Bank Indonesia No. 10/19/PBI/2008 menjelaskan bahwa Dana Pihak Ketiga untuk selanjutnya disebut DPK adalah kewajiban bank kepada penduduk dalam rupiah dan valuta asing. Umumnya dana yang dihimpun oleh perbankan dari masyarakat akan digunakan untuk pendanaan aktivitas sektor riil melalui penyaluran kredit atau pembiayaan.

\section{c. Biaya Tenaga Kerja}

Biaya Tenaga Kerja merupakan usaha fisik atau mental yang dikeluarkan karyawan untuk mengolah produk. Biaya tenaga kerja adalah harga yang dibebankan untuk penggunaan biaya tenaga kerja manusia.

2. Variabel Output

Variabel output yang digunakan dalam penelitian ini adalah sebagai berikut:

a. Total Kredit atau Pembiayaan 
Total kredit atau pembiayaan merupakan produk utama bank sebagai lembaga intermediasi yang menghubungkan antara pihak yang kelebihan dana (surplus) dengan pihak yang kekurangan dana (defisit).

\section{b. Total Pendapatan}

Total pendapatan merupakan hasil dari kegiatan operasional maupun nonoperasional bank yang tergolong bank asing maupun bank swasta nasional.

\section{Hasil Penelitian}

Pada pembahasan ini akan ditampilkan tingkat efisiensi 5 Bank Perkreditan Rakyat Konvensional (BPRK) dan 5 Bank Pembiayaan Rakyat Syariah (BPRS), melalui metode Data Envelopment Analysis (DEA) selama periode 2014-2017 maupun tingkat efisiensi rata-rata yang dicapai oleh BPRK dan BPRS selama periode penelitian. Data tentang variabel input dan variabel output diperoleh dari Laporan Keuangan Triwulan BPRK dan BPRS Jawa Timur di Otoritas Jasa Keuangan. Dalam DEA, apabila hasil pengukuran yang muncul adalah 1 atau 100, menunjukkan bahwa kemampuan suatu BPRK atau BPRS dalam mengoptimalkan seluruh sumber daya yang dimiliki, sedangkan apabila skor yang muncul semakin menjauhi 1 atau 100 mengindikasikan BPRK atau BPRS belum optimal dalam menjalankan perannya sebagai lembaga intermediasi.

Hasil analisis tingkat efisiensi perbankan untuk kelompok BPR dan BPRS tahun 2014-2017 menggunakan metode Data Envelopment Analysis (DEA) dapat dilihat pada Tabel 2 dan Tabel 3. Terdapat dua BPR Konvensional yang mencapai efisiensi $100 \%$ selama periode penelitian tahun 2014-2017, yaitu BPR Delta Purnama dan BPR Arta Nawa. Sedangkan tiga BPR lainnya, yakni BPR Benta Tesa, BPR Nusamba Genteng dan BPR Bina Reksa Karya Utama belum mencapai tingkat efisiensi. BPR Benta Tesa memiliki rata- rata efisiensi 99.81\%, BMR Nusamba Genteng memiliki rata-rata efisiensi 99.68\%, sedangkan BPR Bina Reksa memiliki rata-rata $99.06 \%$. Meskipun ketiga BPR tersebut belum mencapai tingkat efisien, namun rata-ratanya sangat mendekati efisien. Rata-rata tingkat efisiensi 5 BPR selama periode penelitian tahun 2014-2017 adalah $99.61 \%$, rata-rata tingkat efisiensi untuk kelompok sampel BPR diperoleh pada tahun 2015, yakni $100 \%$.

Tabel 2. Rata-Rata Tingkat Technical Efficiency 5 Bank Perkreditan Rakyat Konvensional (BPRK) di Jawa Timur Tahun 2014-2017 Menggunakan BCCVRS (dalam presentase)

\begin{tabular}{|c|c|c|c|c|c|}
\hline \multirow[t]{2}{*}{ Nama BPR } & \multicolumn{4}{|c|}{ Tahun } & \multirow{2}{*}{$\begin{array}{l}\text { Rata- } \\
\text { Rata }\end{array}$} \\
\hline & 2014 & 2015 & 2016 & 2017 & \\
\hline $\begin{array}{l}\text { BPR Benta } \\
\text { Tesa }\end{array}$ & 100 & 100 & 99.25 & 100 & 99.81 \\
\hline $\begin{array}{l}\text { BPR } \\
\text { Nusamba } \\
\text { Genteng }\end{array}$ & 99.25 & 100 & 100 & 99.5 & 99.68 \\
\hline $\begin{array}{l}\text { BPR Bina } \\
\text { Reksa }\end{array}$ & 100 & 100 & 100 & 96.25 & 99.06 \\
\hline $\begin{array}{l}\text { BPR Delta } \\
\text { Purnama }\end{array}$ & 100 & 100 & 100 & 100 & 100 \\
\hline $\begin{array}{l}\text { BPR Arta } \\
\text { Nawa }\end{array}$ & 100 & 100 & 100 & 100 & 100 \\
\hline Rata-Rata & 99.45 & 100 & 99.85 & 99.15 & 99.61 \\
\hline
\end{tabular}

Pada kelompok sampel BPR Syariah, tidak ada BPR yang mengalami efisiensi sempurna, tingkat rata-rata efisiensi tertinggi dimiliki oleh BPRS Amanah Sejahtera sebesar 99.43\%. BPRS Bakti Makmur Indah 97.68\%, BPRS Lan Tabur Tebuireng 99.25\%, BPRS Mitra Mandiri Sukses 99.06\% dan BPRS Bumi Rinjani Kepanjen 99.37\%. Meskipun dalam kelompok BPR Syariah tidak ada yang mencapai efisiensi, masing-masing sampel BPR Syariah memiliki tingkat efisiensi $<97 \%$. Rata-rata tingkat efisiensi 5 BPRS selama periode penelitian tahun 2014-2017 adalah $98.96 \%$, rata-rata tingkat efisiensi tertinggi untuk kelompok sampel BPRS diperoleh pada tahun 2014 sebesar $99.75 \%$. 
Tabel 3. Rata-Rata Tingkat Technical Efficiency 5 Bank Perkreditan Rakyat Syariah (BPRS) di Jawa Timur Tahun 2014-2017 Menggunakan BCC-VRS (dalam presentase)

\begin{tabular}{|c|c|c|c|c|c|}
\hline \multirow[t]{2}{*}{ Nama BPRS } & \multicolumn{4}{|c|}{ Tahun } & \multirow{2}{*}{$\begin{array}{l}\text { Rata- } \\
\text { Rata }\end{array}$} \\
\hline & 2014 & 2015 & 2016 & 2017 & \\
\hline $\begin{array}{l}\text { BPRS Bakti } \\
\text { Makmur } \\
\text { Indah }\end{array}$ & 100 & 98 & 98 & 94.75 & 97.68 \\
\hline $\begin{array}{l}\text { BPRS } \\
\text { Amanah } \\
\text { Sejahtera }\end{array}$ & 99 & 99.25 & 99.5 & 100 & 99.43 \\
\hline $\begin{array}{l}\text { BPRS Lan } \\
\text { Tabur } \\
\text { Tebuireng }\end{array}$ & 100 & 98.5 & 99.5 & 99 & 99.25 \\
\hline $\begin{array}{l}\text { BPRS } \\
\text { Mandiri } \\
\text { Mitra } \\
\text { Sukses }\end{array}$ & 100 & 98.25 & 98.5 & 99.5 & 99.06 \\
\hline $\begin{array}{l}\text { BPRS Bumi } \\
\text { Rinjani } \\
\text { Kepanjen }\end{array}$ & 99.75 & 100 & 97.75 & 100 & 99.37 \\
\hline Rata-Rata & 99.75 & 98.8 & 98.65 & 98.65 & 98.96 \\
\hline
\end{tabular}

Hasil pengukuran tingkat efisiensi untuk kelompok sampel BPR Konvensional dan BPR Syariah diperoleh hasil bahwa tingkat efisiensi kelompok BPR Konvensional selama periode penelitian tahun 2014-2017 belum mencapai skor efisiensi 100\%. Hal ini menunjukkan bahwa $\mathrm{H}_{1}$ yang menyatakan bahwa tingkat efisiensi BPR Konvensional belum mencapai tingkat efisiensi $100 \%$ dapat diterima. Berikutnya hasil pengujian juga mendukung pernyataan $\mathrm{H}_{2}$ bahwa tingkat efisiensi kelompok sampel BPR Syariah belum mencapai $100 \%$. Rata-rata sampel BPR Syariah belum mutlak mencapai tingkat efisiensi $100 \%$, berbeda dengan sampel BPR Konvensional yang memiliki efisiensi $100 \%$ yang stabil dari tahun 2014-2017. Akan tetapi, bukan berarti BPR Syariah tidak pernah mencapai tingkat efisiensi $100 \%$ karena apabila kita lihat hasil pengukuran efisiensi per kuartalnya 5 sampel BPR Syariah pernah mencapai tingkat efisiensi $100 \%$.

Dari 5 sampel BPR Konvensional di Jawa Timur tahun 2014-2017, dua BPR yang memiliki rata-rata efisiensi $100 \%$ yakni BPR Delta Purnama dan BPR Arta Nawa. BPR Benta Tesa memiliki rata-rata efisiensi $99.81 \%$, BPR Nusamba Genteng memiliki rata-rata efisiensi $99.68 \%$, sedangkan BPR Bina Reksa memiliki ratarata $99.06 \%$. Meskipun ketiga BPR tersebut belum mencapai tingkat efisien, namun rataratanya sangat mendekati efisien. Apabila kita lihat dalam Tabel. 6 yang menyajikan tingkat efisiensi per kuartal dari tahun 20142017, BPR Benta Tesa dan BPR Nusamba Genteng mengalami penurunan efisiensi pada September 2016 dan September 2014. Sedangkan BPR Bina Reksa Karya Utama mengalami penurunan efisiensi berturutturut, yakni Maret 2017, Juni 2017 dan September 2017.

Tabel 6. Tingkat Technical Efficiency 5 Bank Perkreditan Rakyat Konvensional (BPRK) di Jawa Timur Kuartal I-IV Tahun 2014-2017 Menggunakan BCC-VRS (dalam presentase)

\begin{tabular}{|c|c|c|c|c|c|}
\hline & $\begin{array}{c}\text { BPRK } \\
\text { BT }\end{array}$ & $\begin{array}{c}\text { BPRK } \\
\text { NG }\end{array}$ & $\begin{array}{c}\text { BPRK } \\
\text { BRK }\end{array}$ & $\begin{array}{c}\text { BPRK } \\
\text { DPS }\end{array}$ & $\begin{array}{c}\text { BPRK } \\
\text { AN }\end{array}$ \\
\hline $\begin{array}{c}\text { Q1 } \\
2014\end{array}$ & 100 & 100 & 100 & 100 & 100 \\
\hline $\begin{array}{c}\text { Q2 } \\
2014\end{array}$ & 100 & 100 & 100 & 100 & 100 \\
\hline $\begin{array}{c}\text { Q3 } \\
2014\end{array}$ & 100 & 97 & 100 & 100 & 100 \\
\hline $\begin{array}{c}\text { Q4 } \\
2014\end{array}$ & 100 & 100 & 100 & 100 & 100 \\
\hline $\begin{array}{c}\text { Q1 } \\
2015\end{array}$ & 100 & 100 & 100 & 100 & 100 \\
\hline $\begin{array}{c}\text { Q2 } \\
2015\end{array}$ & 100 & 100 & 100 & 100 & 100 \\
\hline $\begin{array}{c}\text { Q3 } \\
2015\end{array}$ & 100 & 100 & 100 & 100 & 100 \\
\hline $\begin{array}{c}\text { Q4 } \\
2015\end{array}$ & 100 & 100 & 100 & 100 & 100 \\
\hline $\begin{array}{c}\text { Q1 } \\
2016\end{array}$ & 100 & 100 & 100 & 100 & 100 \\
\hline $\begin{array}{c}\text { Q2 } \\
2016\end{array}$ & 100 & 100 & 100 & 100 & 100 \\
\hline $\begin{array}{c}\text { Q3 } \\
2016\end{array}$ & 97 & 100 & 100 & 100 & 100 \\
\hline $\begin{array}{c}\text { Q4 } \\
2016\end{array}$ & 100 & 100 & 100 & 100 & 100 \\
\hline $\begin{array}{c}\text { Q1 } \\
2017\end{array}$ & 100 & 100 & 97 & 100 & 100 \\
\hline $\begin{array}{c}\text { Q2 } \\
2017\end{array}$ & 100 & 100 & 97 & 100 & 100 \\
\hline $\begin{array}{c}\text { Q3 } \\
2017\end{array}$ & 100 & 98 & 91 & 100 & 100 \\
\hline $\begin{array}{c}\text { Q4 } \\
2017\end{array}$ & 100 & 100 & 100 & 100 & 100 \\
\hline $\begin{array}{l}\text { Rata- } \\
\text { Rata }\end{array}$ & 99.81 & 99.68 & 99.06 & 100 & 100 \\
\hline
\end{tabular}


Apabila diamati, BPR Syariah yang paling sering mencapai tingkat efisiensi dari kuartal I-IV dalam periode penelitian tahun 2014-2017 adalah BPRS Bumi Rinjani Kepanjen. Penurunan efisiensi BPRS Bumi Rinjani Kepanjen terjadi pada Juni 2014 dan September 2016, yakni 99\% dan 91\%. BPRS Amanah Sejahtera mengalami tiga kali penurunan tingkat efisiensi sedangkan BPRS Lan Tabur Tebuireng dan BPRS Mandiri Mitra Sukses empat kali mengalami penuruan efisiensi. BPRS Bakti Makmur Indah paling sering mengalami penurunan hingga delapan kali dalam waktu yang hampir berturut-turut, yakni September 2015, Desember 2015, Maret 2016 dan Desember 2016 dan sepanjang tahun 2017 terus mengalami penurunan tingkat efisiensi, akan tetapi masih $>90 \%$.

Tabel 7. Tingkat Technical Efficiency 5 Bank Pembiayaan Rakyat Syariah (BPRS) di Jawa Timur Kuartal I-IV Tahun 2014-2017 Menggunakan BCC-

VRS (dalam presentase)

\begin{tabular}{|c|c|c|c|c|c|}
\hline & $\begin{array}{c}\text { BPRS } \\
\text { BMI } \\
\end{array}$ & $\begin{array}{c}\text { BPRS } \\
\text { AS } \\
\end{array}$ & $\begin{array}{l}\text { BPRS } \\
\text { LTT } \\
\end{array}$ & $\begin{array}{l}\text { BPRS } \\
\text { MMS } \\
\end{array}$ & $\begin{array}{l}\text { BPRS } \\
\text { BRK }\end{array}$ \\
\hline $\begin{array}{c}\text { Q1 } \\
2014\end{array}$ & 100 & 100 & 100 & 100 & 100 \\
\hline $\begin{array}{c}\text { Q2 } \\
2014\end{array}$ & 100 & 96 & 100 & 100 & 99 \\
\hline $\begin{array}{c}\text { Q3 } \\
2014\end{array}$ & 100 & 100 & 100 & 100 & 100 \\
\hline $\begin{array}{c}\text { Q4 } \\
2014\end{array}$ & 100 & 100 & 100 & 100 & 100 \\
\hline $\begin{array}{c}\text { Q1 } \\
2015\end{array}$ & 100 & 100 & 100 & 97 & 100 \\
\hline $\begin{array}{c}\text { Q2 } \\
2015\end{array}$ & 100 & 100 & 100 & 100 & 100 \\
\hline $\begin{array}{c}\text { Q3 } \\
2015\end{array}$ & 98 & 100 & 95 & 96 & 100 \\
\hline $\begin{array}{c}\text { Q4 } \\
2015\end{array}$ & 94 & 97 & 99 & 100 & 100 \\
\hline $\begin{array}{c}\text { Q1 } \\
2016\end{array}$ & 96 & 100 & 100 & 100 & 100 \\
\hline $\begin{array}{c}\text { Q2 } \\
2016\end{array}$ & 100 & 100 & 100 & 100 & 100 \\
\hline $\begin{array}{c}\text { Q3 } \\
2016\end{array}$ & 100 & 98 & 98 & 94 & 91 \\
\hline $\begin{array}{c}\text { Q4 } \\
2016\end{array}$ & 96 & 100 & 100 & 100 & 100 \\
\hline $\begin{array}{c}\text { Q1 } \\
2017\end{array}$ & 98 & 100 & 100 & 100 & 100 \\
\hline $\begin{array}{c}\text { Q2 } \\
2017\end{array}$ & 97 & 100 & 100 & 100 & 100 \\
\hline $\begin{array}{c}\text { Q3 } \\
2017\end{array}$ & 93 & 100 & 96 & 98 & 100 \\
\hline
\end{tabular}

\begin{tabular}{cccccc}
\hline $\begin{array}{c}\text { Q4 } \\
\mathbf{2 0 1 7}\end{array}$ & 91 & 100 & 100 & 100 & 100 \\
$\begin{array}{c}\text { Rata- } \\
\text { Rata }\end{array}$ & $\mathbf{9 7 . 6 8}$ & $\mathbf{9 9 . 4 3}$ & $\mathbf{9 9 . 2 5}$ & $\mathbf{9 9 . 0 6}$ & $\mathbf{9 9 . 3 7}$ \\
\hline
\end{tabular}

Hasil pengukuran tingkat efisiensi 5 sampel Bank Perkreditan Konvensional dan 5 sampel Bank Pembiayaan Rakyat Syariah selama periode penelitian 2014-2017 membuktikan bahwa BPR Konvensional memiliki rata-rata tingkat efisiensi sebesar 99.61\% sedangkan BPR Syariah memiliki rata-rata efisiensi sebesar $98.96 \%$. Hasil pengukuran efisiensi terhadap BPR Konvensional dan BPR Syariah mendukung hipotesis penelitian, yaitu $\mathrm{H}_{1}$ : tingkat efisiensi Bank Perkreditan Rakyat Konvensional (BPRK) pada periode 20142017 belum mencapai tingkat efisiensi sempurna $(100 \%)$ dan $\mathrm{H}_{2}$ : tingkat efisiensi Bank Pembiayaan Rakyat Syariah (BPRS) pada periode 2014-2017 belum mencapai efisiensi sempurna (100\%).

Belum tercapainya tingkat efisiensi 100\% BPR Konvensional di Jawa Timur sama dengan penelitian Suliyanto dan Dian Purnomo Jati (2014) berjudul Perbandingan Efisiensi Bank Perkreditan Rakyat dan Bank Umum dengan Pendekatan Data Envelopment Analysis, BPR Konvensional belum mencapai efisiensi $100 \%$, dengan rata-rata tingkat efisiensi BPR Konvensional sebesar 87\%. Salah satu faktor penyebab inefisiensi BPR Konvensional adalah pengeluaran pada variabel input berupa personal expenses (biaya tenaga kerja) yang berlebihan atau melebihi target optimal. Septianto dan Widiharih (2010) berjudul Analisis Efisiensi Bank Perkreditan Rakyat di Kota Semarang dengan Pendekatan Data Envelopment Analysis, yang menyatakan bahwa kinerja BPR Konvensional belum mencapai efisiensi $100 \%$. Hal ini karena dari 16 BPR Konvensional yang diteliti hanya 6 yang efisien, sedangkan 10 belum efisien.

Penelitian Muhammad Nasihin dan Ludwina Harahap (2014) berjudul The 
Analysis of The Efficiency of BPRS: Production Function Approach VS Financial Ratios Approach, menyimpulkan bahwa berdasarkan pendekatan fungsi produksi BPRS menunjukkan tingkat efisiensi di atas 90\% (artinya selama periode penelitian tidak ada BPRS yang mencapai tingkat efisiensi 100\%). Pola efisiensi menurut penelitian Nasihin dan Harahap menunjukkan fluktuasi tingkat efisiensi, ketika berada dalam level tinggi tak lama akan menurun. Hal ini wajar karena faktor-faktor persaingan yang berdampak positif bahkan negatif terhadap efisiensi BPR Syariah. Efisiensi BPR Syariah yang belum mencapai $100 \%$ juga ditunjukkan oleh penelitian Muhamad Nadratuzzaman Hosen dan Syafaat Muhari (2013) berjudul Efficiency of The Sharia Rural Bank in Indonesia Lead to Modified CAMEL selama periode Juni 2011 sampai dengan Desember 2012 rata-rata tingkat efisiensi BPR Syariah di Indonesia adalah sebesar $81.41 \%$, dengan tingkat efisiensi paling tinggi dimiliki oleh BPRS Bakhti Sumekar sebesar $97.77 \%$ dan tingkat efisiensi paling rendah dimiliki BPRS Masyarakat Ummat Indonesia sebesar $60.07 \%$.

Inefisiensi BPR Konvensional dari sisi input disebabkan oleh seluruh variabel input, yakni aset, biaya tenaga kerja dan dana pihak ketiga. BPR Benta Tesa yang memiliki rata-rata efisiensi $99.81 \%$, inefisiensi disebabkan oleh variabel input aset, biaya tenaga kerja dan dana pihak ketiga. Berbeda dengan BPR Nusamba Genteng, inefisiensi disebabkan oleh variabel input aset, biaya tenaga kerja dan dana pihak ketiga, juga dari sisi output, kredit. Sedangkan inefisiensi 5 sampel BPR Syariah tidak berbeda jauh dengan BPR Konvensional, seluruh variabel input mendominasi menjadi penyebab inefisiensi. BPRS Lan Tabur Tebuireng, misalnya, memiliki tingkat efisiensi $<100 \%$ pada September 2015, Desember 2015, September 2016 dan sepanjang tahun 2017.
Inefisiensi pada sisi output terdapat pada variabel pembiayaan, sedangkan pendapatan operasional efisien. Sedangkan inefisiensi pada BPRS Bumi Rinjani Kepanjen dikarenakan oleh seluruh variabel input, yakni: aset, dana pihak ketiga dan biaya tenaga kerja.

Hasil pengolahan Data Envelopment Analysis (DEA) menunjukkan bahwa variabel input yang paling berpengaruh terhadap inefisiensi BPR Konvensional maupun BPR Syariah. Selain persoalan biaya tenaga kerja (personal expenses), meliputi: gaji, tunjangan, bonus, insentif dan bentuk kompensasi lainnya yang berlebihan bahkan melebihi target optimal. BPR Konvensional maupun BPR juga mengalami persoalan terkait dana menganggur (iddle fund), sehingga sebagai lembaga keuangan intermediasi semestinya BPR Konvensional maupun BPR Syariah mampu meningkatkan pembiayaan atau kredit terhadap masyarakat, yang juga akan berdampak pada pendapatan bank atau keuntungan bank.

\section{Penutup}

Berdasarkan metode Data Envelopment Analysis (DEA) dapat diperoleh kesimpulan, sebagai berikut:

1. Kelima sampel BPR Konvensional yang menjadi objek penelitian hanya ada dua BPR yang mencapai rata-rata tingkat efisiensi 100\%, yaitu: BPR Delta Purnama dan BPR Arta Nawa. Hal ini terlihat dari skor technical efficiency selama 8 kuartal dari Maret 2014 sampai dengan Desember 2017. Inefisiensi tertinggi pada sampel BPR Konvensional terjadi pada BPR Bina Reksa Karya Utama, karena pada September 2017 tingkat efisiensi hanya 91\% padahal tahun sebelumnya mencapai $100 \%$. Pada BPR Syariah inefisiensi terjadi pada BPR Bumi Rinjani Kepanjen pada September 2016 tingkat efisiensi hanya $91 \%$ padahal efisiensi di tahun sebelumnya dan 
setelahnya cukup stabil, yakni mencapai 100\%. Sedangkan BPR Bakti Makmur Indah pada Desember 2017 tingkat efisiensi hanya mencapai $91 \%$, karena memang sepanjang tahun 2017 BPR Bakti Makmur Indah tidak mencapai efisiensi $100 \%$.

2. Kelima sampel BPR Syariah yang menjadi obyek penelitian tidak satupun mengalami rata-rata tingkat efisiensi $100 \%$, walaupun jika dilihat per tahunnya ada yang mencapai tingkat efisiensi $100 \%$. Hal ini terlihat pada technical efficiency selama 16 kuartal dari Maret 2014 sampai dengan Desember 2017, rata-rata efisiensi tertinggi dicapai oleh BPRS Amanah Sejahtera dengan skor efisiensi $99.43 \%$. Sedangkan skor rata-rata efisiensi paling rendah dimiliki oleh BPRS 98.96\%.

3. Meskipun tidak ada yang mencapai rata-rata efisiensi $100 \%$, efisiensi BPR Syariah masih $>97 \%$, hal ini sangat berbeda dengan dua sampel BPR Konvensional yang dapat mencapai skor $100 \%$. Secara skor rata-rata per BPR, BPR Konvensional unggul karena dua sampel nya, yakni BPR Delta Purnama dan BPR Arta Nawa mencapai tingkat efisiensi $100 \%$. Salah satu BPR Syariah yang mencuri perhatian adalah BPRS Bakti Makmur Indah yang inefisiensi di empat kuartal sekaligus pada tahun 2017. Penurunan terjadi stabil dimulai pada kuartal I sampai dengan kuartal 2017. Hal ini belum pernah terjadi di tahun sebelumnya pada BPRS Bakti Makmur Indah, terlebih tidak pernah terjadi pada sampel BPR Syariah maupun BPR Konvensional.

4. Pada sisi input, ketidakefisienan pada kelima BPR Konvensional maupun BPR Syariah berasal dari seluruh variabel input, yakni aset, dana pihak ketiga dan biaya tenaga kerja. Pada sisi output, inefisiensi BPR tersebut ratarata berasal dari kredit atau pembiayaan.

\section{Daftar Pustaka}

Abidin, Zaenal dan Endri. 2009. Kinerja Efisiensi Teknik Bank Pembangunan Daerah: Pendekatan Data Envelopment Analysis (DEA). Jurnal Akuntansi dan Keuangan. Volume 11 Nomor 1 hal 21-29,

Abu Husain Muslim bin Al-Hajjaj. 1918. Shahih Muslim Jilid I. Kairo: Dar AlKutub,

Affandi, N.M. Islam and Business. 2002. Subang Jaya: Pelanduk Publication (M) Sdn.Bhd.

Bank Indonesia. 2009. Laporan Keuangan Publikasi Bank BPR Konvensional Tahun. Diunduh tanggal 19 Juli 2018, http://www.bi.go.id

Bank Indonesia. 2017. Statistik Perbankan BPR Konvensoanl-Indikator Utama. tanggal 19 Juli 2018, http://www.bi.go.id

Berger, A.N dan Humphrey, D.B. 1997. Efficiency of Financial Institutions: International Survey and Directions for Future Research. European Journal of Operation Research, 98(5): 175-212.

Buchori, A. 2003. Kajian Kinerja Industri BPRS di Indonesia. Buletin Ekonomi Moneter dan Perbankan, 5(4): 64-123.

Eka Putri Noor, V.S.D. 2013. Analisis Perbandingan Efisiensi Bank Syariah dan Bank Konvensional dengan Menggunakan Metode Data Envelopment Analysis. Skripsi. Jakarta. UIN Syarif Hidayatullah

Endri dan Abdul Wakil. 2008. Analisis Kinerja Keuangan dengan Menggunakan Rasio-Rasio Keuangan dan Economic Value Added (Studi 
Kasus: PT. Bank Syariah Mandiri). Jurnal Ekonomi, 1(13):123-140.

Hamka. 2007. Tafsir Al-Azhar Jus XV. Jakarta: Pustaka Panjimas.

Hartono, I, Setiadi Djohar dan Heny K.Daryanto. 2008. Analisis Efisiensi Bank Perkreditan Rakyat di Wilayah Jabodetabek dengan Pendekatan Data Envelopment Analysis. Jurnal Manajemen dan Agribisnis, 5(2):5263.

Ismail, F, Majid MSA, dan Rahim RA. 2013. Efficiency of Islamic Conventional Banks in Malaysia. Journal of Financial Reporting and Accounting, 11(1):92-107.

Kamaruddin, Badrul Hisham. et.al. 2008. Assesing Production Efficiency of Islamic Banks and Conventional Bank Islamic Windows in Malaysia. International Journal of Business and Management Science, Vol 1(1), pp. 31-48.

Kusumawardani, D. 2008. Tingkat Kesehatan dan Efisiensi Bank Perkreditan Rakyat Jawa Timur. Majalah Ekonomi Universitas Airlangga, 18(2):114-132.

Muharam, H dan Rizki Pusvitasari. 2007. Analisis Perbandingan Efisiensi Bank Syariah dengan Metode Data Envelopment Analysis (Periode Tahun 2005). Jurnal Ekonomi dan Bisnis Islam Vol. 2 No. 3.

Muhari, Syafaat dan Muhamad Nadratuzzaman Hosen. 2014. Tingkat Efisiensi BPRS di Indonesia: Perbandingan Metode SFA dengan DEA dan Hubungannya dengan CAMEL. Jurnal Keuangan dan Perbankan, Vol. 18, No. 2 Mei.

Nashihin, Muhammad dan Ludwina Harahap. 2014. The Analysis of The Efficiency of BPRS: Production
Function VS Financial Ratios Approach. Procedia Social and Behavioral Sciences 115(188-197), Elsevier Publishing.

Nia, N.M, Alouji H.A, Pireivatlou, A.S dan Ghezelbash, A. 2012. A Comparative Profitability Efficiency Study of Private and Government Banking System in Iran Applying Data Envelopment Analysis (DEA). Journal of Basic and Applied Scientific Research, 2(11): 1160311614.

Otoritas Jasa Keuangan. 2017. Statistik Perbankan Syariah (Sharia Banking Statistic). Jakarta: Otoritas Jasa Keuangan.

Purwanto, Erwan Agus dan Byah Ratih Sulistyatuti. 2011. Metode Penelitian Kuantitatif untuk Administrasi Publik dan Masalah-Masalah Sosial. Yogyakarta: Gava Media.

Setiawan, Arief. 2013. Analisis Perbandingan Efisiensi Bank Konvensional dan Bank Syariah dengan Menggunakan Metode Data Envelopment Analysis (DEA) (Periode 2008-2012). Skripsi. Jakarta. UIN Syarif Hidayatullah.

Siamat, Dahlan. 1999. Manajemen Lembaga Keuangan Edisi Kedua. Jakarta: Lembaga Penerbit Fakultas Ekonomi Universitas Indonesia.

Suliyanto dan Dian Purnomo Jati. 2014. Perbandingan Efisiensi Bank Perkreditan Rakyat dan Bank Umum dengan Pendekatan Data Envelopment Analysis. Jurnal Keuangan dan Perbankan,Vol.18, No.2 Mei .

Tempo.Co.2017. Dibanding Akhir 2016, Ekonomi Kuartal I 2017 turun 0-34 persen. Diunduh tanggal 17 Juli 2018, https://bisnis.tempo.co 